\title{
Oral health of neonates: mothers' perception of lingual frenotomy performed in a university hospital
}

\author{
Saúde bucal de neonatos: percepção das mães sobre a frenotomia \\ lingual realizada em um hospital universitário
}

\author{
Bruna SIQUEIRA' ${ }^{1}$ iD https://orcid.org/0000-0002-4665-1680 \\ Fabiana Bucholdz Teixeira ALVES² iD https://orcid.org/0000-0001-9955-1811 \\ Luciane Patrícia Andreani CABRAL ${ }^{3}$ iD https://orcid.org/0000-0001-9424-7431 \\ Danielle BORDIN ${ }^{4}$ iD https://orcid.org/0000-0001-7861-0384 \\ Melina Lopes LIMA5 ${ }^{5}$ https://orcid.org/0000-0002-8266-4040 \\ Cristina Berger FADEL2 iD https://orcid.org/0000-0002-7303-5429
}

\section{ABSTRACT}

Objective: The study sought to know mothers' perception of neonates on lingual frenotomy performed by a dental care program of a university hospital in Paraná. Methods: It is a descriptive research with a qualitative approach, developed with mothers of newborns and whose children were submitted to a lingual frenzy procedure during maternal hospitalization ( $\mathrm{n}=09$ ). Data were collected through a focus group interview and analyzed according to the content analysis technique. Results: It was identified five thematic nuclei linked to lingual frenotomy in infants: 'maternal impressions agaisnt the professional indication'; 'Family trial'; 'Need to perform frenotomy'; 'Feelings after the completion of the frenotomy'; 'Changes in baby behavior'. The main maternal impressions were linked to fear and suffering related to the babies reaction. Regarding to the need to perform the lingual frenotomy, the intrinsic opinions were initially divergent, however, all evidenced that the procedure was indispensable for the baby, mainly for speech. After the frenotomy completion, the mothers reported well-being for the improvement in the lingual physiology and babies' quality of life, with emphasis on breastfeeding and improvement in the baby's behavior. Conclusion: The results obtained are encouraging for the hospital managers to consider, in their clinical protocols, the technique of lingual frenotomy in newborns, with a view to facilitating mothers' access to the procedure, qualifying breastfeeding and consequently expanding the maternal and child bond.

Indexing terms: Neonatology. Oral health. Social perception.

$\boldsymbol{\nabla} \mathbf{\nabla} \boldsymbol{\nabla}$

1 Hospital Universitário Regional dos Campos Gerais, Residência Multiprofissional em Neonatologia. Ponta Grossa, PR, Brasil.

2 Universidade Estadual de Ponta Grossa, Departamento de Odontologia. Av. Carlos Cavalcante, 4748, Bloco M, Campus Uvaranas, 84030-000, Ponta Grossa, PR, Brasil. Correspondence to: FBT Alves. E-mail: <fabi.bucholdz@gmail.com>.

3 Hospital Universitário Regional dos Campos Gerais, Comissão de Residência Multiprofissional. Ponta Grossa, PR, Brasil.

${ }^{4}$ Universidade Estadual de Ponta Grossa, Departamento de Enfermagem e Saúde Pública. Ponta Grossa, PR, Brasil.

5 Hospital Universitário Regional dos Campos Gerais, Residência Multiprofissional em Urgência e Emergência. Ponta Grossa, PR, Brasil.

$\boldsymbol{\nabla} \boldsymbol{\nabla} \boldsymbol{\nabla}$

How to cite this article

Siqueira B, Alves FBT, Cabral LPA, Bordin D, Lima ML, Fadel CB. Oral health of neonates: mothers' perception of lingual frenotomy performed in a university hospital. RGO, Rev Gaúch Odontol. 2020;68:e20200023. http://dx.doi.org/10.1590/1981-863720200002320180008 


\section{RESUMO}

Objetivo: Conhecer a percepção de mães de neonatos sobre a frenotomia lingual, realizada por um programa de atenção odontológica de um hospital universitário do Paraná. Métodos: Trata-se de pesquisa descritiva com abordagem qualitativa, desenvolvida junto a mães de recém-nascidos e cujos filhos sofreram o procedimento de frenotomia lingual durante a internação materna ( $n=09$ ). Os dados foram coletados por meio de entrevista em grupo focal e analisados conforme a técnica de análise de conteúdo. Resultados: Identificou-se cinco núcleos temáticos atrelados a frenotomia lingual em bebês: 'impressões maternas frente a indicação profissional'; 'julgamento da família'; 'necessidade de realização da frenotomia'; 'sentimentos após a realização da frenotomia'; 'alterações no comportamento do bebê'. As principais impressões maternas estavam atrelados ao medo e sofrimento relacionadas à reação dos bebês. Quanto à necessidade de realização da frenotomia lingual, as opiniões intrínsecas foram inicialmente divergentes, entretanto, todas evidenciaram que o procedimento era indispensável ao seu bebê, principalmente para a fala. Após a realização da frenotomia, as mães relataram bem-estar pela melhoria na fisiologia lingual e qualidade de vida dos bebês, com ênfase na amamentação e melhora no comportamento do bebê. Conclusão: Os resultados alcançados são encorajadores para gestores de hospitais considerarem, em seus protocolos clínicos, a técnica da frenotomia lingual em recém-nascidos, com vistas à facilitação do acesso de mães ao procedimento, à qualificação da amamentação materna e à consequente ampliação do vínculo maternoinfantil.

Termos de indexação: Neonatologia. Saúde bucal. Percepção social.

\section{INTRODUCTION}

Attention to oral and perinatal oral health for hospitalized patients has revealed singular importance, not only for the actions of maternal and family education and prevention, but also for the purpose of improving the quality of life of these individuals. In Brazil, the performance of the dental surgeon in hospital has been growing in recent years and it is already part of the national reality [1], and early dental care is presented as an opportunity for the child to have the possibility of reducing the risk of some oral complaints that have repercussions on health as a whole.

In this sense, it is highlighted here the anomaly called ankyloglossia or shortening of the free lingual portion, understood as an anatomical condition marked by the restriction of tongue movement, caused by a bad-insertion of the lingual frenulum during embryonic development [2] and which, being associated to functional aspects related to craniofacial growth and development [3] and to social aspects [4].

In neonates, this condition has reported rates varying from $4 \%$ to $11 \%$ [5], and may have significant impacts on the anatomical, physiological and cognitive balance of the baby [6], with interferences in breastfeeding [7]. In this bias, the challenge of breastfeeding is exposed to neonates with strongly inserted lingual frenulum, with unfolding in the maturation of their perioral musculature and, consequently, in the development of correct breathing, swallowing and, subsequently, occlusion [8].

In Brazil, the law establishing the application of a protocol for the evaluation of the lingual frenulum of infants, popularly known as 'tongue test', in hospitals and maternity hospitals, public or private, has recently been sanctioned [9]. This procedure aims preventing complications that prevet breastfeeding as ankyloglycosis, due to deficiencies in sucking and swallowing functions and their associations, such as low weight gain and early weaning $[10,11]$.

Despite numerous controversies regarding to the best diagnosis method of this anatomical lingual condition [12], the indication of clinical-surgical intervention in neonates, called frenotomy or frenulotomy, has been gradually diffused, with evidence of objective and subjective benefits in the diet and general health of infants [11].

In this sense, the study sought to know the mothers' perception of newborn children on the procedure called lingual frenotomy, performed by a dental care program of a university hospital in Paraná.

\section{METHODS}

This is a descriptive research with a qualitative approach, developed with mothers of newborns who were hospitalized at the Regional University Hospital of Campos Gerais (HURCG), in Ponta Grossa-PR town, from March 2017 to July 2018 and whose children underwent lingual frenotomy during maternal hospitalization ( $n=155)$. As exclusion criteria it was not considered mothers residing outside the hospital's headquarters.

For the data collection, a lottery of twenty mothers was carried out, which were, though phone contact, invited to compose a focal group interview at the Higher 
Education Institution linked to the referred hospital. Of these, nine came to the research place. For the recruitment of the subjects it was considered that, even with the possible loss of $50 \%$, common in research using indirect means the call of participants, the sample would still be satisfactory for the qualitative research.

The interview that lasted approximately forty minutes, was conducted by a single researcher, recorded and transcribed in full for later analysis. To gather information, it was used a script composed of guiding questions, which referred to the mothers' perception investigated about the lingual frenulum performed in their child during the hospital stay. The researcher responsible for this stage exercised the role of advisor, explaining to the participants the method that would be used and its unfolding, and the functions of motivator and moderator, allowing the participants to express freely in the moments they deem appropriate and sustaining their interest in interview. A pilot study was carried out with mothers of newborns who underwent lingual frenotomy at the hospital in the period prior to data collection, in order to evaluate the comprehension of the vocabulary that would be used. The data collection instrument was not modified after this study. Closing of the data collection occurred according to the saturation criterion, that is, when the analysis of the empirical material allowed to delineate a comprehensive scenario by the object of study.

The data obtained were analyzed according to the content analysis technique, in the cross-thematic analysis modality described by Bardin. This approach consists of a set of communication analysis techniques, aiming at obtaining, through systematic and objective procedures to describe the content of the messages, indicators that allow the inference of knowledge regarding the conditions of production and reception of the express messages [13].

For the analysis, which was also performed by a single researcher and in a manual way, the speeches were cut out, taking into account the constancy of the themes extracted from the speeches, in order to find the main nuclei of meaning, whose presence gave meaning to the objective proposed [14]. Five thematic nuclei were linked to the process of lingual frenotomy in infants: 'maternal impressions against the professional indication'; 'Family trial'; 'Need to perform frenotomy'; 'Feelings after the completion of the frenotomy'; 'Changes in baby behavior'. The most representative speeches of each category were transcribed ipsis litteris and discussed in light of relevant literature.
The study accepted the norms of Resolution 466/12 and was approved by the Research Ethics Committee (opinion no. 2,461,494/2018). All the participants signed the Free and Informed Consent Term and had their anonymity assured.

\section{RESULTS}

The average age of the mothers interviewed was 26 years and the predominant marital status was married or stable union, with four having a single child and the other mothers with two or more children. In relation to schooling, there was a predominance of the incomplete average level, and the average family income declared was three minimum wages. As professional occupation, five affirmed that they did not have a formal job, two were merchants, a maid and a nursing assistant. The totality of the mothers resided in the municipality of the hospital of interest for this study.

The conceptions presented by the mothers about the procedure of lingual frenotomy in infants consisted of five main thematic nuclei, namely: maternal impressions against the professional indication; family judgment; need to perform the frenotomy; feelings after the frenotomy completion; changes in the baby's behavior.

\section{Maternal impressions compared to the professional indication}

The majority reported being frightened by acknowledging or receiving information that their baby had a stuck tongue, alleging a relationship to social distress, difficulty in speaking and breastfeeding. Only one exposed naturalness to the baby's oral condition, claiming that another child had already been born under this condition. The main maternal indications for the indication of the frenotomy were fear and suffering, often related to the reaction of the babies.

"I got scared, I thought it hurt, he had difficult to suckle because of the "curtain", but it was all quiet".

"It's just that I got scared, I mean, I was afraid to move like that, right there. I also got pity, damn it, it's going to hurt, but he came so calm, it was all right".

"I was scared, so she asked me about my other two children, I said that neither of them had, they were born normal, then she said that he had a tongue tied, I got 
scared, then she said let's just make him have no problem anymore if leaving it can be a problem, but it's scary".

\section{Family trial}

The family trial, when faced to maternal decisionmaking regarding to the frenotomy, was exposed as another factor perceived as relevant by the interviewees.

"I called her and I said: Mom, they will bump into his tongue, she was pretty scared, why are you going to do this? And I became more afraid, wondering if it was the right thing to be done. They do not understand, then I explained ... in the case they say that he stays stutter and gets a lot of thing, that can not speak properly. And she was quiet, and say to do".

\section{Need to perform the frenotomy}

Regarding to the need to perform the lingual frenotomy, the intrinsic opinions were initially divergent, however, all evidenced that the procedure was indispensable for their baby.

"In my opinion, yes (I think it's necessary), because I've seen cases of people who have their tongue stuck, certain sounds they do not pronounce correctly, so it was important for me to do it, if it was not done in the hospital, I would find other means of doing".

"Also (considers necessary) I do not know if it's by having a cut of the tongue, I have a problem to talk about, it's a little whistled, it's a few things, I wanted it so she would not suffer from it either".

"No (I do not think it's necessary), but my sister-in-law who was with me told me that it was good to do not to suffer because he says that whoever has more ahead is dangerous right ?! Can not talk, these things. So it was good to do it".

\section{Feelings after the frenotomy completion}

Regarding to the feelings of the interviewees after the frenotomy completion, the statements mentioned the feeling of well-being due to the condition of improvement in the lingual physiology and the quality of life of the babies, with emphasis on the breastfeeding process.
"I was relieved that he was able to suckle better, and was able to get his tongue out, make the correct breastfeed, so I was relieved that it was right. That the way was right ..." ".

"I was more relieved because of him sucking, not taking (suction for breastfeeding), now he is getting much better than before".

\section{Changes in baby behavior}

On the perceived alterations in the behavior of the baby after the accomplishment of the frenotomy, important behavioral advances were pointed out.

"He was calmer, because he cried a lot I think because he could not breastfeed right, he was still hungry, but he did the little thing there, he totally changed his behavior, he was a whiner, he was calmer, calm".

"He was crying a lot, could not take his tongue out there, you know? Now he's calmer".

\section{DISCUSSION}

Early maternal fear reactions to the frenzied procedure, as well as the familiar expressions, suggest the importance of the Language Test (LT) diffusion and its unfolding with all those involved to the birth. The birth of a child is a unique moment, which generates expectation in which all relatives, often accompanied by an instinctive feeling of protection to the baby [15]. In this sense, the need for early diagnosis and demystification of the ankyloglossia anomaly is reinforced, avoiding maternal and family reactions that tend to generate embarrassment, fear, guilt and anger [16] in the face of a lack of knowledge of a particular situation.

The mothers' expressions also show that when the space of the unknown is filled, through the access to information and the experience of a reassuring situation linked to the accomplishment of the frenotomy in the newborn, they assume the role of disseminators in health before their family. People's health information behavior, which is how people seek, obtain, evaluate, categorize and use relevant health-related information to perform desired health behaviors, is a critical prerequisite for appropriate and consistent performance of these behaviors [17].

Thus, the importance of the knowledge dissemination about TL and the frenotomy among mothers 
of neonates is reiterated, identifying their sensitivity in the information behaviors, with a view to the success of promotion and intervention in health actions.

Regarding to the need to perform the lingual frenotomy, the intrinsic maternal opinions were initially divergent, however, all evidenced that the procedure was essential for the baby. A recent systematic review study, which evaluated lingual frenulum in newborns, concluded that the procedure leads in the short term to a reduction in mothers' nipple pain and an inconsistent positive effect on the child's breastfeeding [18], which could reinforce subjectivity exposed by the mothers of the present study regarding to the efficacy of the procedure. No study reviewed by the authors was able to report whether the frenotomy led to successful long-term breastfeeding, since most of them evaluated only the first feeding after intervention [18].

The lack of scientific evidence about the object under study and its consequences brings with it different postures of health professionals (dentists, pediatricians, breastfeeding consultants and speech therapists), who have been controversial about the clinical significance and management of ankyloglossia. Those that reinforce the indication of the frenotomy in neonates with ankyloglossia are based on the condition that the free movement of the tongue is proven of fundamental importance for sucking and swallowing during breastfeeding [3]. Thus, any difficulty in performing lingual movement could lead to impairment of these orofacial functions, resulting in early weaning and low weight gain $[10,11]$, in addition to being related to maternal nipple pain and damage [19] and also to the maternal feeling of inability to nourish the your baby [20].

It should be pointed out, however, that although the frenotomy suggests an improvement in breastfeeding, it is worth noting that other factors, such as posture and fetus related to the mother and child binomial, are supporting in this process, which highlights the importance of the instrumentalization of a team multiprofessional and education of mothers of newborns [21].

Also, as exposed by the mothers investigated, it is evident the necessity of the frenotomy in newborns seeking to anticipate or minimize possible social constraints that the limitation of the lingual movement can have on the quality of life of these individuals. In fact, the lower motricity of the tongue makes it difficult for simple everyday actions related to the articulation of speech and the consumption of certain types of food, causing social situations that are quite embarrassing [4].

Regarding to the feelings of those interviewed after the completion of the frenotomy, the speeches referred to the feeling of well-being by the condition of improvement. Despite the complex network of support and care provided at the birth of a child, the decisionmaking process of caring is traditionally presented as an intrinsically maternal condition associated to a family culture in the care line and, consequently, to different orders of behavior and attitudes. Also, attention to the birth of the baby offered by a constant figure, usually the mother, who responds contingently to their demands, will favor the baby's safe and healthy physical, cognitive and emotional development [22].

In this sense, the comfort feeling expressed by the mothers investigated after the frenotomy procedure is justified, by identifying their contribution to the progress of the neonate in the breastfeeding process and by attesting to their own assertive decision making. It is emphasized that the quality of maternal interaction and response to the demands of the baby becomes fundamental for their (baby's)[23] emotional regulation, being, maternal breastfeeding, an act of extreme bonding between mother and child and great maternal emotion [24], with benefits attesting to the neonate [22] daily progress.

Thus, it is natural for maternal discourses to take the place of feelings and perceptions of relief in relation to their investment in the relationship of closeness to the child, favoring the exchange of affection, the bonding and the physiology of the baby.

Finally, about the perceived changes in the behavior of the baby after the performance of the frenotomy, important behavioral improvements were pointed out.

The benefits observed after the frenotomy involve improvement in the movement and lingual position of the neonate, besides a better lip position, relieving the discomforts at the time of breastfeeding and favoring a correct handgrip within the mother $[25,26]$. This improvement in mothers' perceptions of ankyloglycosis on breastfeeding can be observed even during hospital admission in their midterm, with evolution at 24 and 72 hours after the frenotomy [7].

In relation to progress of the baby's behavioral and emotional aspects, as evidenced by the maternal speech, 
studies show that they can be influenced by breastfeeding, either by the direct effects of specific nutrients in breast milk in the developing brain [27], or by mother-infant interactions which occur during feeding [28]. Still, some authors maintain that this potential beneficial impact of breastfeeding on emotional development may persist in childhood [29] and others refute this idea [27]; however, without denying the well-established benefits of breastfeeding and efforts to support its initiation, continuation and exclusivity. It is emphasized here that although maternal breastfeeding is not a worldwide precept, the best results are achieved when interventions are implemented simultaneously through various channels, such as legal and policy guidelines, social attitudes and values, working conditions and women's employment and health services [30].

Finally, in spite of the positive effects found in the present study on the qualification of maternal breastfeeding and the consequent increase in the maternal infant bond after lingual frenotomy, there remains a need for a greater number of studies with deepening and methodological rigor for the safe decision making on the ducts health clinics for newborns.

Regarding to the limitations, it is worth noting that although the qualitative method is capable of deepening the complexity of the analyzed phenomenon, as is the case of the maternal perception about the lingual frenzy in babies analyzed by the present study, there is no possibility of inference and generalization of the results for a larger universe. Also, taking into account the performance of this procedure in a reference hospital of the regional health network, where many subjects belonged to towns other than the research site, they were not considered in the sampling process due to the geographical barriers to data collect.

\section{CONCLUSION}

Despite the mothers' feelings about the recognition that their baby was carrying the congenital anomaly known as ankyloglossia and the subsequent realization of lingual frenotomy, they experienced sensations of fear, suffering, social judgment and doubts, they also perceived this procedure as indispensable for socialization and to the quality of life of their children, with improvements in the behavioral and emotional aspects of the baby.

The family's judgment regarding to the decision to perform lingual frenotomy was also perceived as relevant by the mothers interviewed, which highlights the importance of family inclusion in this context.

\section{Collaborators}

B SIQUEIRA collected data and wrote the manuscript. FBT ALVES assisted in the analysis and interpretation of the data. LPA Cabral and ML LIMA conducted a critical review of the content. D BORDIN conducted the methodological step, analyzed and interpretation of the data. CB FADEL elaborated the conception and designed the study. All authors discussed the results and commented on the manuscript at all stages. The manuscript read and approved by all the authors, and each author believes the manuscript represents honest work.

\section{REFERENCES}

1. Euzebio LF, Viana KA, Cortines $A A O$, Costa LR. Atuação do residente cirurgião-dentista em equipe multiprofissional de atenção hospitalar à saúde materno-infantil. Rev Odontol Bras Central. 2013;21(60):16-20.

2. Katchburian E, Arana V. Histologia e embriologia oral: texto, atlas, correlações clínicas. $3^{a}$ ed. Rio de Janeiro: Guanabara Koogan; 2012.

3. Walsh J, Tunkel D. Diagnosis and Treatment of Ankyloglossia in Newborns and Infants: A Review. JAMA Otolaryngol Head Neck Surg. 2017;143(10):1032-1039. https://doi.org/10.10 01/jamaoto.2017.0948

4. Suzart DD, Carvalho ARR. Alterações de fala relacionadas às alterações do frênulo lingual em escolares. Rev. CEFAC. 2016; 18(6):1332-1339. https://doi.org/10.1590/1982-0216 201618621715

5. O'Shea JE, Foster JP, O'Donnell CPF, Breathnach D, Jacobs $\mathrm{SE}$, Todd DA, et al. Frenotomy for tongue-tie in newborn infants. Cochrane Database Syst Rev. 2017 Mar, Issue 3. Art. No.: CD011065. https://doi.org/10.1002/14651858.CD011065. pub2

6. Meenakshi S, Jagannathan, N. Assessment of lingual frenulum lengths in skeletal malocclusion. J Clin Diagn Res. 2014;8(3):202-204. https://doi.org/10.7860/JCDR/2014/7079. 4162

7. Almeida KR, Leal TP, Kubo H, Castro TES, Ortolan CLF. Frenotomia lingual em recém-nascido, do diagnóstico à cirurgia: relato de caso. Rev CEFAC. 2018;20(2):258-262. https://doi.org/10.1590/1982-0216201820212917

8. Brookes A, Bowley DM. Tongue tie: the evidence for frenotomy. Early Hum Dev. 2014; 90(11): 765-8. https://doi. org/10.1016/j.earlhumdev.2014.08.021

9. Brasil. Ministério da Saúde. Lei $n^{\circ} 13.002$, de 20 junho de 2014. Obriga a realização do Protocolo de Avaliação do Frênulo da Língua em Bebês. Brasília: Ministério da Saúde; 2014. Disponivel em: <https://www.sbfa.org.br/fono2014/ pdf/testelinguinha_2014_livro.pdf>. 
10. Ferrés-Amat E, Pastor-Vera T, Ferrés-Amat E, MarequeBueno J, Prats-Armengol J, Ferrés-Padró E. Multidisciplinary management of ankyloglossia in childhood. Treatment of 101 cases. A protocol. Med Oral Patol Oral Cir Bucal. 2016;21(1):39-47. https://doi.org/10.4317/medoral.20736

11. Martinelli RLC, Marchesan IQ, Gusmão RJ, Honório HM, Berretin-Felix $G$. The effects of frenotomy on breastfeeding. J Appl Oral Sci. 2015;23(2):153-157. https://doi.org/10.15 90/1678-775720140339

12. Pompéia LE, Ilinsky RS, Ortolani CLF, Júnior KF. A influência da anquiloglossia no crescimento e desenvolvimento do sistema estomatognático. Rev Paul Pediatr. 2017;35(2):216-221. https://doi.org/10.1590/1984-0462

13. Bardin L. A análise de conteúdo. $4^{\mathrm{a}}$ ed. Lisboa: Edições 70; 2009.

14. Minayo MCS. O desafio do conhecimento: pesquisa qualitativa em saúde. 13a ed. São Paulo: Hucitec; 2013.

15. Thorstensson S, Hertfelt Wahn E, Ekström A, Langius-Eklöf A. Evaluation of the Mother-to-Infant relation and feeling scale: Interviews with first-time mothers' for feelings and relation to their baby three days after birth. Int J Nurs Midwifery. 2012;4(1):8-15. https://doi.org/10.5897/IJNM11.041

16. Gomes GA, Piccinini AC. Malformação no bebê e maternidade: aspectos teóricos e clínicos. Psic Clin. 2010;22(1):15-38. https://doi.org/10.1590/S0103-56652010000100002

17. Hirvonen N, Huotari ML, Niemelä R, Koperlainen R. Information behavior in stages of exercise behavior change. J Am Soc Inf Sci Technol. 2012;63(9):1804-1819. https://doi. org/10.1002/asi.22704

18. O'shea JE, Foster JP, O'Donnell CPF, Breathnach D, Jacobs SE, Todd DA, et al. Frenotomy for tongue-tie in newborn infants. Cochrane Database Syst Rev. 2017;3(CD011065):1-35. https:// doi.org/10.1002/14651858.CD011065.pub2.

19. Berry J, Griffiths M, Westcott C. A DoubleBlind, Randomized, Controlled Trial of TongueTie Division and Its Immediate Effect on Breastfeeding. Breastfeed Med. 2012;7(3):189-93. https:// doi.org/10.1089/bfm.2011.0030

20. Gerd AT, Bergman S, Dahlgren J, Roswall J, Alm B. Factors associated with discontinuation of breastfeeding before 1 month of age. Acta Paediatr. 2012;101(1):55-60. https://doi. org/10.1111/j.1651-2227.2011.02405.x

21. Venancio SI, Buccini C, Toma T, Araujo C, Sanches MTC, Figueiró MF. Anquiloglossia e aleitamento materno: evidências sobre a magnitude do problema, protocolos de avaliação, segurança e eficácia da frenotomia. São Paulo: Instituto de Saúde; 2015.

22. Santo CSOE, Araújo MAN. Vínculo afetivo materno: Processo fundamental à saúde mental. Rev Psicologia, Diversidade e Saúde. 2016;5(1):65-73. https://doi.org/10.17267/2317-3394 rpds.v5i1.831

23. Menegatti CL, Pianovski MAD, Lohr SS. Interações iniciais entre pais, mães e bebês de 0 a 3 anos: revisão de literatura. Estud Psicol. 2016;21(4):381-391. https://doi.org/10.5935/1678-46 69.20160037

24. D'artibale EF, Bercini LO. O contato e a amamentação precoces: significados e vivências. Texto Contexto Enferm. 2014;23(1):109-117.

25. Mcclellan HL, Kent JC, Hepworth Anna R, Hartmann PE, Geddes DT, Scott J, et al. Persistent nipple pain in breastfeeding mothers associated with abnormal infant tongue movement. Int J Environ Res Public Health. 2015;12(9):10833-10845. https://doi.org/10.3390/ijerph120910833

26. Procopio IMS, Costa VPP, Lia EN. Frenotomia lingual em lactentes. RFO Passo Fundo. 2017;22(1):114-119. https://doi. org/10.5335/rfo.v22i1.6849

27. Belfort MB, Anderson PJ, Nowak VA, Lee KJ, Molesworth C, Thompson DK, et al. Breast milk feeding, brain development, and neurocognitive outcomes: a 7-year longitudinal study in infants born 30 weeks' gestation. J Pediatr. 2016;177:133-139. https://doi.org/10.1016/j.jpeds.2016.06.045

28. Cerezo MA, Trenado RM, Pons-Salvador G. Mother-infant interaction and quality of child's attachment: a nonlinear dynamical systems approach. Nonlinear Dynamics Psychol Life Sci. 2012; 16(3):243-267.

29. Victora CG, Bahl R, Barros AJD, Franca GVA, Horton S, Krasevec J, Murch S, Richter L. Breastfeeding in the 21st century: epidemiology, mechanisms, and lifelong effect. Lancet. 2016; 387(10017): 475-490. https://doi.org/10.1016/ S0140-6736(15)01024-7

30. Rollins NC, Bhandari N, Hajeebhoy N, Horton S, Lutter CK, Martines JC, et al. Why invest, and what it will take to improve breastfeeding practices? Lancet. 2016; 387(10017): 491-504. https://doi.org/10.1016/S0140-6736(15)01044-2

Received on: 29/10/2018 Final version resubmitted on: 7/2/2019 Approved on: 8/3/2019 